Benoît Ruot, Denis Breuillé, Fabienne Rambourdin, Gerard Bayle, Pierre Capitan and Christiane Obled

Am J Physiol Endocrinol Metab 279:244-251, 2000.

You might find this additional information useful...

This article cites 38 articles, 14 of which you can access free at:

http://ajpendo.physiology.org/cgi/content/full/279/2/E244\#BIBL

This article has been cited by 9 other HighWire hosted articles, the first 5 are:

Threonine Utilization for Synthesis of Acute Phase Proteins, Intestinal Proteins, and

Mucins Is Increased during Sepsis in Rats

M. Faure, F. Chone, C. Mettraux, J.-P. Godin, F. Bechereau, J. Vuichoud, I. Papet, D. Breuille and C. Obled

J. Nutr., July 1, 2007; 137 (7): 1802-1807.

[Abstract] [Full Text] [PDF]

Using $2 \mathrm{H} 2 \mathrm{O}$ to study the influence of feeding on protein synthesis: effect of isotope equilibration in vivo vs. in cell culture

D. A. Dufner, I. R. Bederman, D. Z. Brunengraber, N. Rachdaoui, F. Ismail-Beigi, B. A.

Siegfried, S. R. Kimball and S. F. Previs

Am J Physiol Endocrinol Metab, June 1, 2005; 288 (6): E1277-E1283.

[Abstract] [Full Text] [PDF]

Nutritional Supplementation Acutely Increases Albumin Fractional Synthetic Rate in Chronic Hemodialysis Patients

L. B. Pupim, P. J. Flakoll and T. A. Ikizler

J. Am. Soc. Nephrol., July 1, 2004; 15 (7): 1920-1926.

[Abstract] [Full Text] [PDF]

Extended Hypermetabolic Response of the Liver in Severely Burned Pediatric Patients M. G. Jeschke, R. E. Barrow and D. N. Herndon

Arch Surg, June 1, 2004; 139 (6): 641-647.

[Abstract] [Full Text] [PDF]

Protein synthesis rates of human PBMC and PMN can be determined simultaneously in vivo by using small blood samples

S. Walrand, C. Guillet, P. Gachon, P. Rousset, C. Giraudet, M.-P. Vasson and Y. Boirie Am J Physiol Cell Physiol, June 1, 2004; 286 (6): C1474-C1478.

[Abstract] [Full Text] [PDF]

Medline items on this article's topics can be found at http://highwire.stanford.edu/lists/artbytopic.dtl on the following topics:

Biochemistry .. Albumins

Biochemistry .. Valine

Microbiology .. Escherichia Coli

Medicine .. Sepsis

Medicine .. Hypoalbuminemia

Physiology .. Rats

Updated information and services including high-resolution figures, can be found at:

http://ajpendo.physiology.org/cgi/content/full/279/2/E244

Additional material and information about AJP - Endocrinology and Metabolism can be found at: http://www.the-aps.org/publications/ajpendo

This information is current as of September 3, 2010 .

AJP - Endocrinology and Metabolism publishes results of original studies about endocrine and metabolic systems on any level of organization. It is published 12 times a year (monthly) by the American Physiological Society, 9650 Rockville Pike, Bethesda MD 20814-3991. Copyright @ 2000 by the American Physiological Society. ISSN: 0193-1849, ESSN: 1522-1555. Visit our website at http://www.the-aps.org/. 


\title{
Synthesis rate of plasma albumin is a good indicator of liver albumin synthesis in sepsis
}

\author{
BENOÎT RUOT, ${ }^{1}$ DENIS BREUILLÉ, ${ }^{2}$ FABIENNE RAMBOURDIN,${ }^{1}$ GERARD BAYLE,${ }^{1}$ \\ PIERRE CAPITAN,${ }^{1}$ AND CHRISTIANE OBLED ${ }^{1}$ \\ ${ }^{1}$ Centre de Recherche en Nutrition Humaine d'Auvergne and Unité d'Etude du Métabolisme Azoté, \\ Institut National de la Recherche Agronomique Theix, 63122 Saint Genès Champanelle, France; \\ and ${ }^{2}$ Nestlé Research Centre, Vers-chez-les-blanc, 1000 Lausanne 26, Switzerland
}

Received 26 October 1999; accepted in final form 24 February 2000

\begin{abstract}
Ruot, Benoît, Denis Breuillé, Fabienne Rambourdin, Gerard Bayle, Pierre Capitan, and Christiane Obled. Synthesis rate of plasma albumin is a good indicator of liver albumin synthesis in sepsis. Am J Physiol Endocrinol Metab 279: E244-E251, 2000.-Plasma albumin is well known to decrease in response to inflammation. The rate of albumin synthesis from both liver and plasma was measured in vivo by use of a large dose of $\mathrm{L}-\left[{ }^{2} \mathrm{H}_{3}-{ }^{14} \mathrm{C}\right]$ valine in rats injected intravenously with live Escherichia coli and in pair-fed control rats during the acute-phase period (2 days postinfection). The plasma albumin concentration was reduced by $50 \%$ in infected rats compared with pair-fed animals. Infection induced a fall in both liver albumin mRNA levels and albumin synthesis relative to total liver protein synthesis. However, absolute liver albumin synthesis rate (ASR) was not affected by infection. In plasma, albumin fractional synthesis rate was increased by $50 \%$ in infected animals compared with pair-fed animals. The albumin ASR estimated in the plasma was similar in the two groups. These results suggest that hypoalbuminemia is not due to reduced albumin synthesis during sepsis. Moreover, liver and plasma albumin ASR were similar. Therefore, albumin synthesis measured in the plasma is a good indicator of liver albumin synthesis.
\end{abstract}

hypoalbuminemia; albumin expression; infection

STRESS (TRAUMA, INFECTION, OR RADIATION) has always been associated with hypoalbuminemia in either animals $(33,40)$ or humans $(9,30)$. A reduction of plasma albumin concentration can be the consequence of various factors, including a change in its rate of synthesis, an increased catabolic rate, and/or a redistribution of albumin from plasma to interstitial compartment. Nevertheless, decreased albumin synthesis has been considered as a primary process causing hypoalbuminemia during injury. On the basis of animal studies, many authors have concluded from a rapid loss of liver albumin mRNA levels that a reduced albumin synthesis occurs in response to various stresses, such as burn (36), turpentine, and lipopolysaccharide (LPS) injections (22) or interleukin (IL)-6 or tumor necrosis factor- $\alpha$ administration $(20,37)$. Otherwise, very few studies have investigated in vivo net albumin biosyn-

Address for reprint requests and other correspondence: C. Obled, Unité d'Etude du Métabolisme Azoté, INRA Theix, 63122 Saint Genés Champanelle, France (E mail: obled@clermont.inra.fr). thesis under severe injury in animal models, and the few available results are controversial. Estimated from $\left[{ }^{14} \mathrm{C}\right]$ leucine incorporation, Schreiber et al. (33) found a decrease in plasma albumin synthesis rate $24 \mathrm{~h}$ after turpentine injection in rats. Ballmer et al. (2) also reported a similar decreased synthesis in IL-1ß-injected rats. By contrast, Sax et al. (31) described an unchanged albumin synthesis in perfused liver $16 \mathrm{~h}$ after celiac puncture in rats, but the same investigators also found that albumin synthesis was increased on day 4 in the same model (41). Injection of endotoxin in rabbits stimulated by $15 \%$ the synthesis rate of albumin measured in the plasma (15).

However, anorexia and reduced caloric intake are prominent symptoms during acute infection (4), and of all factors regulating albumin synthesis, the nutritional state appears to be the most important (27). Most studies reporting a decreased albumin synthesis in response to injury compared the treated animals with well-fed animals $(2,33)$. Therefore, the decreased synthesis observed may result from the decreased food intake rather than from the inflammatory stress.

By contrast, results in humans show increasing evidence that albumin synthesis did not decrease during stress. Mansoor et al. (19) reported an increase of albumin synthesis rate in head trauma patients despite a decrease in albumin plasma concentration. In a more recent study, Fearon et al. (9) reported a $34 \%$ increase of albumin synthesis rate in cancer patients with hypoalbuminemia. The measurement of synthesis of plasma proteins at their site of synthesis, i.e., liver, is rarely possible in humans. Therefore, methods used are often indirect, and measurements have principally been made in plasma. However, for albumin, the intravascular space represents only $40 \%$ of its total exchangeable pool, and the question remains whether an estimation of albumin synthesis in the intravascular space could be a good indicator of total liver synthesis of the protein.

The aim of this study was, first, to measure in the same animals liver albumin mRNA expression and

The costs of publication of this article were defrayed in part by the payment of page charges. The article must therefore be hereby marked "advertisement" in accordance with 18 U.S.C. Section 1734 solely to indicate this fact. 
synthesis and, second, to correlate total albumin synthesis in the liver with synthesis estimated in the intravascular pool. Moreover, to determine specifically the effect of infection, these experiments were performed by comparison to animals that were pair-fed to the intake of infected rats.

\section{MATERIALS AND METHODS}

\section{Animals and Experimental Design}

Male Sprague-Dawley rats (IFFA-Credo, l'Abresle, France) of $\sim 250 \mathrm{~g}$ body weight $(n=36)$ were maintained in individual cages at $22^{\circ} \mathrm{C}$-controlled temperature on a 12:12-h light-dark cycle (lights on at 0700). They were fed on a semisynthetic diet containing $12 \%$ protein (5). The diet was given in six meals per day via an automatic device. During the entire experiment, animals had free access to water.

After an acclimatization period of 6 days, rats were divided into four groups. Rats in groups 1 and 3 were infected with live Escherichia coli injected into a lateral tail vein (INF rats), as described previously (6). The other groups, groups 2 and 4 , were injected with the same volume of saline. Because infection induced a strong anorexia, the last two groups were pair-fed ( $\mathrm{PF}$ rats) to the intake of infected animals. All animals were studied during the acute septic phase of the model, 2 days after infection. The ethics committee of our research institute approved the protocol, which was conducted in conformity with the National Research Council's Guide for the Care and Use of Laboratory Animals.

Experiment 1. Rates of protein synthesis were measured in vivo with the flooding dose technique as described by Garlick et al. (11) in groups 1 (INF) and 2 (PF). Rats of the two groups ( $n=12$ in each group) received a bolus injection of L-valine ( $150 \mu \mathrm{mol} / 100 \mathrm{~g}$ body wt, $0.5 \mathrm{ml} / 100 \mathrm{~g}$ body wt) containing $\mathrm{L}-\left[1-{ }^{4} \mathrm{C}\right]$ valine $(0.05 \mu \mathrm{Ci} / \mu \mathrm{mol}$; Amersham Life Science, Courtaboeuf, France) and L- $\left[4,4,4-{ }^{2} \mathrm{H}_{3}\right]$ valine (60 atom \%; MassTrace, Woburn, MA). In each group, one animal was killed under pentobarbital sodium anesthesia $(6.0 \mathrm{mg} / 100 \mathrm{~g}$ body wt; Sanofi Santé Animale, Libourne, France) at 8, 11, $14,17,20,23,35,38,41,44,47$, and 50 min after tracer injection. Blood was collected from the abdominal aorta, and plasma was separated by centrifugation and kept at $-20^{\circ} \mathrm{C}$ until analysis. The liver was rapidly removed, rinsed in cold $0.9 \% \mathrm{NaCl}$ to remove blood, blotted, weighed, and frozen in liquid nitrogen. Total liver proteins and hepatic albumin syntheses were measured in rats killed between 8 and 23 min, i.e., before secretion of labeled albumin. Moreover, albumin synthesis was measured in plasma from rats killed between 35 and $50 \mathrm{~min}$.

Experiment 2. The effect of infection on plasma volume was determined in groups 3 (INF) and 4 (PF). The day of the study, under general anesthesia (Imalgene, Rhône-Merieux, France), and for each rat of both groups $(n=12)$, catheters were inserted into the carotid artery and the contralateral jugular vein. Hematocrits were determined on $100 \mu \mathrm{l}$ of venous blood samples (Minosvet, Roche, Paris, France). Evans blue dye $(0.05 \mathrm{mg} / 100 \mathrm{~g}$; Sigma $)$ in $300 \mu \mathrm{l}$ of $0.9 \% \mathrm{NaCl}$ was injected into the jugular vein. Blood samples $(700 \mu l)$ were taken from the carotid artery every 3 min from 3 min up to $15 \mathrm{~min}$ after injection. After separation by centrifugation, plasma was removed and its optical density was measured at $620 \mathrm{~nm}$.

\section{Total Liver and Plasma Protein Syntheses}

Free and protein-bound valine specific radioactivities and enrichments were determined as described previously in de- tail by Breuillé et al. (5). Briefly, liver was finely powdered in liquid nitrogen in a ball mill (Dangoumeau, Prolabo, Paris, France). A 2-g aliquot of frozen liver powder or $1 \mathrm{ml}$ of plasma was homogenized in 8 volumes of ice-cold $10 \%$ TCA. Homogenates were centrifuged $\left(5,000 \mathrm{~g}, 15 \mathrm{~min}, 4^{\circ} \mathrm{C}\right)$. Supernatants containing free amino acids were desalted by cation-exchange chromatography (AG $50 \times 8,100-200$ mesh, H+ form, Bio-Rad, Richmond, CA) in minidisposal columns. Valine and other amino acids were eluted with $4 \mathrm{M} \mathrm{NH}_{4} \mathrm{OH}$. After evaporation of $\mathrm{NH}_{4} \mathrm{OH}$ under vacuum, free amino acids were resuspended in either $0.2 \mathrm{M}$ lithium citrate buffer, $\mathrm{pH}$ 2.2 , for specific radioactivity measurements or $\mathrm{HCl} 0.01 \mathrm{~N}$ for enrichment measurements. TCA-insoluble materials were then washed in cold 10\% TCA (to remove free amino acids). Protein pellets were defatted with methanol-chloroform (1:2, $\mathrm{vol} / \mathrm{vol}$ ) and hydrolyzed in $6 \mathrm{M} \mathrm{HCl}$, at $115^{\circ} \mathrm{C}$, for $48 \mathrm{~h}$. HCl was removed by evaporation, and the residue was resuspended in either $0.2 \mathrm{M}$ lithium citrate buffer, $\mathrm{pH} 2.2$, for specific radioactivity measurements or $\mathrm{HCl} 0.01 \mathrm{~N}$ for enrichment measurements.

RNA contents were measured in the TCA-insoluble material. An aliquot $(0.25 \mathrm{~g})$ was resuspended in $5 \mathrm{ml} 0.3 \mathrm{M} \mathrm{NaOH}$ and incubated at $37^{\circ} \mathrm{C}$ for $1 \mathrm{~h}$, and then $2 \mathrm{ml}$ of $0.2 \mathrm{M} \mathrm{HClO}_{4}$ were added. Samples were centrifuged $\left(10,000 \mathrm{~g}, 5 \mathrm{~min}, 4^{\circ} \mathrm{C}\right)$, and RNA was determined spectrophotometrically in the supernatant as described by Munro and Fleck (23).

Measurement of specific radioactivity. Free and proteinbound valine concentrations were measured after separation by liquid chromatography (resin Benson BP-AN6, Benson, Reno, NE) with an automatic amino acid analyzer. The corresponding radioactivity was measured by solid scintillation in a flow detector (Flo One; Radiomatic Instrument and Chemicals, Tampa, FL) placed immediately after the column.

Measurement of enrichments. The measurement of free or protein-bound valine enrichments was done as their $t$-butyldimethylsilyl (TBDMS) derivatives under electron impact ionization by gas chromatography (GC-MS), with an HP5890 gas chromatograph coupled with an HP-5972 organic mass spectrometer quadrupole (Hewlett-Packard, Paris, France). Enrichments were expressed in mole \% excess.

\section{Purification of Hepatic Albumin and Measurements of Synthesis Rates}

Measurement of albumin absolute synthesis rate with the radioactive tracer. The rate of albumin synthesis in liver relative to total hepatic protein synthesis was evaluated by immunoprecipitation, as described previously (25), in the same rats as those used to measure liver protein synthesis. Liver $(0.5 \mathrm{~g})$ was homogenized in 3 volumes of $0.35 \mathrm{M}$ sucrose-50 mM Tris acetate buffer, $\mathrm{pH} 7.4$ (Sigma). Protein content was determined on liver homogenates by the bicinchoninic acid procedure (BCA; Pierce Chemical, Rockford, IL) (38).

To determine the radioactivity in total liver proteins, 100 $\mu \mathrm{l}$ of homogenate were treated with $5 \mathrm{ml} 10 \%$ cold TCA and centrifuged $\left(10,000 \mathrm{~g}, 20 \mathrm{~min}, 4^{\circ} \mathrm{C}\right)$. The pellet was dissolved in $0.5 \mathrm{ml}$ of $\mathrm{H}_{2} \mathrm{O}$ and $0.5 \mathrm{ml}$ of $0.6 \mathrm{M} \mathrm{NaOH}$ and was incubated at $37^{\circ} \mathrm{C}$. After $1 \mathrm{~h}, 5 \mathrm{ml}$ of $10 \%$ cold TCA were added, and the mixture was centrifuged $(9,000 \mathrm{~g}, 15 \mathrm{~min}$, $4^{\circ} \mathrm{C}$ ). The pellet was washed with $5 \mathrm{ml}$ of $5 \%$ cold TCA. The final pellet was dissolved into $2 \mathrm{ml}$ of $0.3 \mathrm{M} \mathrm{NaOH}$ one night at room temperature, and radioactivity was determined with a Packard 460 CD liquid scintillant spectrometer.

The rest of the initial homogenate was centrifuged (13,000 $g, 10 \mathrm{~min}, 4^{\circ} \mathrm{C}$ ), the supernatant was kept, and the pellet was washed with $1 \mathrm{ml}$ of PBS, $\mathrm{pH}$ 7.2. The two supernatants were 
pooled. One hundred microliters of anti-rat albumin antibody (produced from a goat in our laboratory) were incubated with $50 \mu \mathrm{l}$ of protein G-Sepharose (Sigma) for $1 \mathrm{~h}$ at room temperature and for $3 \mathrm{~h}$ at $4^{\circ} \mathrm{C}$. Then, $300 \mu \mathrm{l}$ of pooled supernatants of infected rats or $200 \mu \mathrm{l}$ of the supernatants of pair-fed rats were added. The amount of supernatant used was determined in preliminary experiments to get maximal precipitation of radioactivity. Mixtures were then incubated for $1 \mathrm{~h}$ at room temperature under slow agitation and centrifuged $\left(5,500 \mathrm{~g}, 5 \mathrm{~min}, 4^{\circ} \mathrm{C}\right)$. The pellet was washed twice with 400 $\mu \mathrm{l}$ of buffer [140 mM NaCl, $5 \mathrm{mM}$ EDTA, $1 \%$ Triton N-100 (wt/vol) and $50 \mathrm{mM}$ Tris, $\mathrm{pH} 7.5$ ] and then with $400 \mu \mathrm{l}$ of buffer (140 mM NaCl, $5 \mathrm{mM}$ EDTA, and $50 \mathrm{mM}$ Tris, $\mathrm{pH} 7.5)$ and taken up in $1 \mathrm{ml}$ of $0.3 \mathrm{M} \mathrm{NaOH}$ for one night at room temperature; $2 \times 500 \mu l$ of these solutions were counted.

Albumin in the initial homogenate was measured by single radial diffusion (18) by use of antibodies raised in our laboratory.

Measurement of albumin fractional synthesis rate with the stable tracer. The fractional synthesis rate of liver albumin (FSR) was calculated from measurement of liver albumin enrichment after separation of antigen from antibody. At the end of immunoprecipitation performed as we have described, $1 \mathrm{ml}$ of $0.01 \mathrm{~N}$ acetic acid was added to the final pellet. The preparation was allowed to stand for one night at room temperature. The precipitate had completely dissolved by this time. Five volumes of pure ethanol were added, and the solution was adjusted to $\mathrm{pH} 2$ with $30 \mu \mathrm{l}$ of $36 \% \mathrm{HCl}$. The mixture was then incubated for $5 \mathrm{~h}$ at room temperature and centrifuged $\left(9,000 \mathrm{~g}, 10 \mathrm{~min}, 4^{\circ} \mathrm{C}\right)$. Purified albumin was in the supernatant. It exhibited a single band on $10 \%$ SDSPAGE (not shown). After evaporation under vacuum, the residue was dissolved into $3 \mathrm{ml}$ of $6 \mathrm{~N} \mathrm{HCl}$ and hydrolyzed for $48 \mathrm{~h}$ at $115^{\circ} \mathrm{C}$. $\mathrm{HCl}$ was removed by evaporation, and the residue was resuspended in $0.01 \mathrm{M} \mathrm{HCl}$. The enrichment of albumin-bound valine was measured as its TBDMS derivative by GC-MS.

\section{Plasma Albumin and Acute-Phase Protein Syntheses}

Albumin from $0.5 \mathrm{ml}$ of plasma from rats killed between 35 and 50 min was purified by affinity chromatography on a 4-ml column of blue Sepharose CL 6B (Pharmacia, Uppsala, Sweden). Nonadhering proteins, essentially total acutephase proteins (APP), were removed by washing the columns with $0.1 \mathrm{M} \mathrm{KCl}-0.05 \mathrm{M}$ Tris $\cdot \mathrm{HCl}, \mathrm{pH} 7.4$, until absorbance returned to baseline. These proteins were precipitated by adding $2 \mathrm{ml} \mathrm{100 \%} \mathrm{TCA} \mathrm{and} \mathrm{were} \mathrm{hydrolyzed} \mathrm{in} 6 \mathrm{M} \mathrm{HCl}$ for $48 \mathrm{~h}$ at $115^{\circ} \mathrm{C}$. The fixed albumin was then eluted with $1.5 \mathrm{M}$ $\mathrm{KCl}-0.05 \mathrm{M}$ Tris $\cdot \mathrm{HCl}, \mathrm{pH} 7.4$, and precipitated by addition of $2 \mathrm{ml}$ of $100 \%$ TCA. Albumin was then washed three times with $10 \%$ TCA and extracted with ethanol. After centrifugation $\left(7,000 \mathrm{~g}, 10 \mathrm{~min}, 4^{\circ} \mathrm{C}\right), \mathrm{HCl}$ was added to get a final concentration of $6 \mathrm{M}$. The protein was hydrolyzed for $48 \mathrm{~h}$ at $115^{\circ} \mathrm{C}$. $\mathrm{HCl}$ was removed by evaporation, and residues were resuspended either in $0.2 \mathrm{M}$ lithium citrate buffer, $\mathrm{pH} 2.2$, for specific radioactivity measurements or in $0.01 \mathrm{~N} \mathrm{HCl}$ for enrichment measurements as described above.

\section{Plasma Protein Concentrations}

Total plasma proteins were determined using biuret protein assay reagent on a Cobas Mira analyzer (Roche Diagnostic Systems, Neuilly sur Seine, France). Plasma APP were measured by single radial diffusion using anti-rat fibrinogen and albumin antibodies (ICN, Cappel, Turnhout, Belgium) and anti-rat $\alpha_{2}$-macroglobulin (A2MG) and $\alpha_{1}$-glycoprotein acid (A1GPA) antibodies raised in rabbits in our laboratory.

\section{Albumin mRNA Quantification}

Total RNA was extracted from $0.2 \mathrm{~g}$ of liver by the method of Chomczynski and Sacchi (7). Twenty micrograms of RNA were separated by electrophoresis in formaldehyde agarose gels (1\%) and transferred electrophoretically to nylon membranes (Gene Screen, NEN Research Products, Boston, MA). RNA was covalently bound to the membrane by ultraviolet cross-linking. Membranes were hybridized with cDNA probe albumin. Hybridizations were conducted overnight at $65^{\circ} \mathrm{C}$ with $\left[{ }^{32} \mathrm{P}\right] \mathrm{cDNA}$ fragments labeled by random priming. After a washing at the same temperature, filters were autoradiographied at $-80^{\circ} \mathrm{C}$ with intensifying screens on hyperfilm MP (Amersham, Buckinghamshire, UK). After stripping of the probe, the filters were reprobed with a mouse $18 \mathrm{~S}$ ribosomal probe (no. 63 178; American Type Culture Collection, Rockville, MD). Autoradiographic signals were quantified by digital image processing and analysis (NIH Image 1.54) and normalized using the corresponding $18 \mathrm{~S}$ rRNA signals to correct for uneven loading.

\section{Calculations}

Protein FSR (in \%/day) was calculated from the formula

$$
\mathrm{FSR}=\mathrm{S}_{\mathrm{b}} \times 100 / \mathrm{S}_{\mathrm{a}}^{\prime} \times t
$$

where $S_{b}$ is the specific radioactivity or enrichment (minus basal enrichment of protein) of protein-bound valine, $t$ is the time animals were killed, and $S_{a}^{\prime}$ is the mean specific radioactivity or enrichment of tissue free valine between time 0 and time $t$. Individual values of $\mathrm{S}_{\mathrm{a}}^{\prime}$ were calculated by multiplying the actual value of $\mathrm{S}_{\mathrm{a}}\left(t_{[1 / 2]}\right)$ obtained at time $t_{[1 / 2]}$ by the ratio of $S_{a}^{\prime}(t)$ to $S_{a}(t)$ obtained from the linear regression of $\mathrm{S}_{\mathrm{a}}$ against time determined from all rats (5). The absolute synthesis rate (ASR) was calculated from the product of FSR and the protein content of tissue and was expressed in milligrams per day.

For albumin FSR measured in the plasma, $\mathrm{S}_{\mathrm{b}}$ is the specific radioactivity or the enrichment of plasma albumin, $\mathrm{S}_{a}^{\prime}$ is the area under the curve of precursor specific radioactivity or enrichment (in the liver) between time points adjusted for the secretion time, and the secretion time was assessed by plotting the individual regression line for the linear part of the albumin enrichment curve and extrapolating to the baseline enrichment (3). ASR of intravascular albumin was then calculated as the product of FSR times plasma albumin concentration $(\mathrm{mg} / \mathrm{ml})$ times plasma volume $(\mathrm{ml})$. FSR of plasma albumin was also calculated using specific radioactivity of liver free valine and albumin-bound valine.

Hepatic albumin synthesis was calculated as the fraction (\%) of liver total protein synthesis, i.e., the fraction of the counts in liver total proteins that was precipitated by antialbumin antibody. The albumin ASR was then calculated by multiplying the albumin synthesis as the fraction of liver total protein synthesis by the absolute rate of liver total protein synthesis. Hepatic albumin FSR can be also deduced from its ASR and its liver content.

Initial plasma volume (IPV) was obtained from the dilution of the dye and the dose of Evans blue initially injected from the formula IPV $=\mathrm{Q} / \mathrm{C}_{0}$, where $\mathrm{Q}$ is the amount of Evans blue injected $(\mathrm{mg})$ and $\mathrm{C}_{0}$ is the initial concentration of Evans blue in $\mathrm{mg} / \mathrm{ml}$ (obtained by linear extrapolation to the $y$-axis). From the IPV and albumin plasma concentration, the mass of circulating albumin was determined. 


\section{Statistical Analysis}

Values are given as means \pm SE. The significance of differences was analyzed by Student's $t$-test. Differences were considered significant when $P<0.05$.

\section{RESULTS}

Infection induced a strong anorexia; infected rats ate only $5-10 \%$ of the amount of food consumed before injection of live bacteria ( $\sim 20 \mathrm{~g} /$ day, Fig. 1$)$. This low food intake resulted in body weight loss in pair-fed animals. However, on day 2 postinfection, infected rats lost more weight than pair-fed control rats, $35.5 \pm 2.9$ and $27.6 \pm 0.7 \mathrm{~g}$, respectively (Fig. 1).

A2MG, A1GPA, and fibrinogen plasma concentrations were significantly greater in septic animals than in pair-fed animals (70, 40, and 2.3 times, respectively; Table 1). Infected rats showed a severe hypoalbuminemia, because albumin levels were reduced by $34 \%$ in

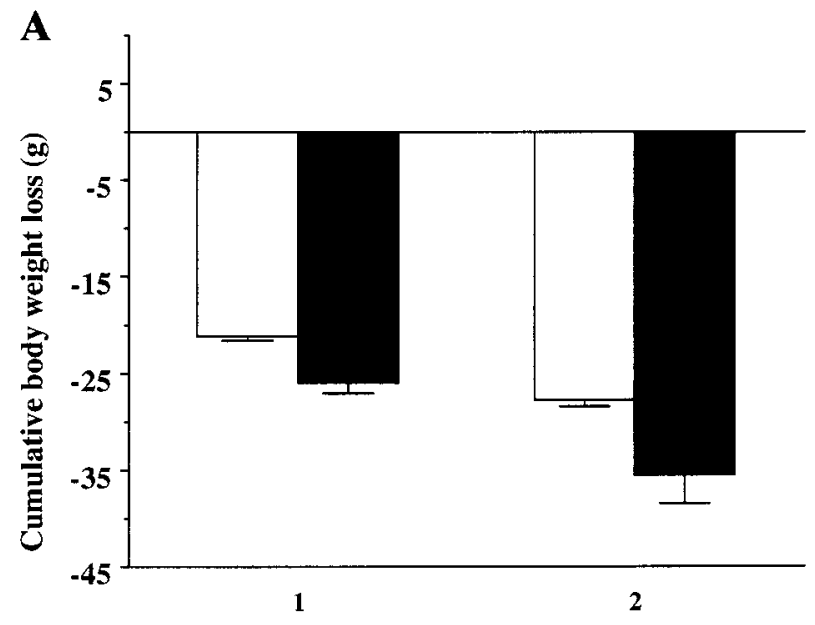

Day after infection

B

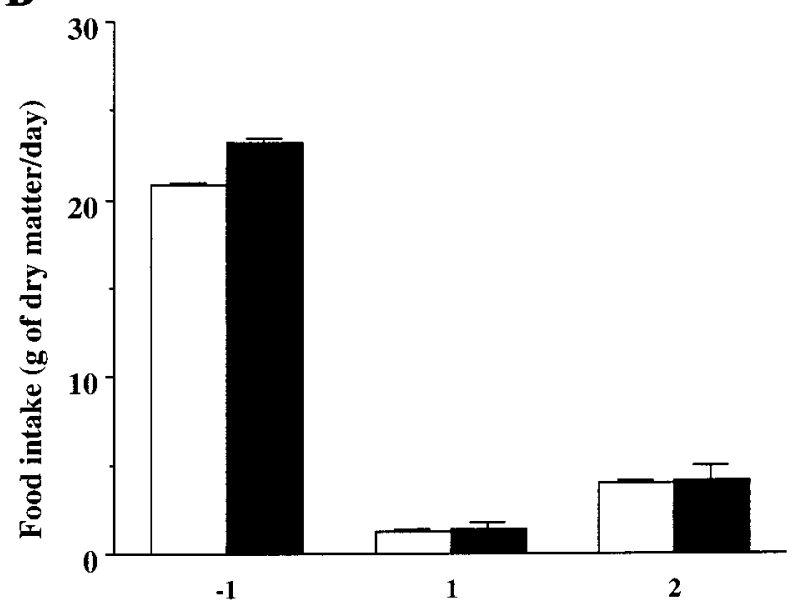

Day / Infection

Fig. 1. Effect of infection on cumulative body weight loss $(A)$ and food intake $(B)$ of rats. Open bars, pair-fed rats (of initial body wt); solid bars, infected rats (of initial body wt). Values are means \pm SE for $n=$ 12 in each group. ${ }^{*} P<0.05$ vs. pair-fed animals.
Table 1. Effect of infection on plasma protein concentrations on day 2 postinfection

\begin{tabular}{lcc}
\hline \hline & Pair-Fed Rats & Infected Rats \\
\hline Fibrinogen, mg/ml & $3.92 \pm 0.24$ & $9.32 \pm 1.05^{*}$ \\
A1GPA, $\mu \mathrm{g} / \mathrm{ml}$ & $25.4 \pm 1.8$ & $1,101 \pm 66^{*}$ \\
A2MG, $\mu \mathrm{g} / \mathrm{ml}$ & $41.4 \pm 6.8$ & $2,866 \pm 557^{*}$ \\
Total proteins, g/l & $61.1 \pm 5.3$ & $51.9 \pm 5.2^{*}$ \\
\hline
\end{tabular}

Rats received an iv injection of either live Escherichia coli (Infected) or saline (Pair-fed). Acute-phase protein plasma levels were determined by single radial diffusion with anti-protein antibodies. Total proteins were determined using the biuret protein assay. Values are means $\pm \mathrm{SE}$ for 6 rats in each group. Statistical significance: $* P<0.05$ vs. pair-fed rats.

these animals compared with pair-fed rats (Table 2). Plasma volumes were similar in both groups, but plasma albumin content was reduced to $61 \%$ by infection. The concentration of albumin in liver was decreased to $55 \%$ in the infected group compared with the pair-fed group. Because infection increased liver weight by $42 \%$, the liver albumin pool was decreased by only $24 \%$ in infected compared with pair-fed rats (Table 2).

\section{Liver Protein Kinetics}

The FSR of liver proteins was 1.4 times higher in septic rats than in pair-fed animals. Applied to liver protein content and expressed as ASR, liver protein synthesis rate was multiplied by 2.5 in septic rats compared with pair-fed animals (Table 3 ). The synthesis rate of plasma proteins minus albumin was measured in the plasma as an index of the synthesis of positive plasma APP. Parallel to an increase in particular APP plasma levels, sepsis stimulated both FSR and ASR values of plasma proteins minus albumin by 50 and $40 \%$, respectively (Table 4 ).

Table 2. Effect of infection on liver weight, liver protein content, liver albumin content, and plasma albumin parameters on day 2 postinfection

\begin{tabular}{lcr}
\hline \hline & Pair-Fed Rats & Infected Rats \\
\hline & Liver & \\
Weight, g & $8.18 \pm 0.14$ & $11.62 \pm 0.14^{*}$ \\
Relative weight, \% of body wt & $3.11 \pm 0.12$ & $4.76 \pm 0.12^{*}$ \\
Total proteins, g & $1.36 \pm 0.8$ & $2.12 \pm 0.64^{*}$ \\
Albumin, mg/g & $2.46 \pm 0.22$ & $1.36 \pm 0.08^{*}$ \\
Albumin pool, mg & $20.9 \pm 1.8$ & $15.8 \pm 1.0^{*}$ \\
& & \\
Plasma volume, ml & Plasma & \\
Albumin, mg/ml & $12.2 \pm 0.3$ & $11.5 \pm 0.3$ \\
Albumin pool, mg & $19.4 \pm 0.8$ & $12.8 \pm 0.6^{*}$ \\
\hline
\end{tabular}

Liver total proteins were determined by the bicinchoninic acid procedure. Liver and plasma albumin levels were determined by the Mancini procedure. Plasma volumes were studied after injection of $0.05 \mathrm{mg} / 100 \mathrm{~g}$ of Evans blue dye into carotid artery. Jugular blood samples were collected at $3,6,9,12$, and 15 min after dye injection. Calculations were performed as described in METHODS. Values are means $\pm \mathrm{SE}$ for 6 rats in each group. Statistical significance: ${ }^{*} P<$ 0.05 vs. pair-fed rats. 
Table 3. Effect of infection on plasma and liver albumin synthesis rates

\begin{tabular}{|c|c|c|}
\hline & Pair-Fed Rats & Infected Rats \\
\hline \multicolumn{3}{|c|}{ Liver } \\
\hline \multicolumn{3}{|l|}{ Total proteins } \\
\hline FSR, \%/day & $87.9 \pm 2.3$ & $122.6 \pm 5.9^{*}$ \\
\hline ASR, g/day & $1.2 \pm 0.7$ & $2.6 \pm 0.1^{*}$ \\
\hline \multicolumn{3}{|l|}{ Albumin } \\
\hline$\%$ TLPS & $9.40 \pm 0.40$ & $4.68 \pm 0.54^{*}$ \\
\hline ASR, mg/day & $110 \pm 9$ & $125 \pm 13$ \\
\hline FSR, \%/day & $386 \pm 39 \dagger$ & $612 \pm 11 * \dagger$ \\
\hline \multicolumn{3}{|c|}{ Plasma } \\
\hline \multicolumn{3}{|c|}{ Albumin synthesis } \\
\hline FSR, \%/day & $54.1 \pm 2.4$ & $104.2 \pm 6.7 *$ \\
\hline ASR, mg/day & $131 \pm 8$ & $157 \pm 8$ \\
\hline \multicolumn{3}{|c|}{$\begin{array}{l}\text { Two days after injections, rats were injected with a flooding dose of } \\
\mathrm{L}-\left[4.4 .4-{ }^{2} \mathrm{H}_{3}\right] \text { valine and }\left[1-{ }^{14} \mathrm{C}\right] \text { valine. Results are given as means } \pm \\
\text { SE for } 5 \text { or } 6 \text { rats in the } 2 \text { groups. TLPS, total liver protein synthesis; } \\
\text { FSR, fractional synthesis rate; ASR, absolute synthesis rate. Statis- } \\
\text { tical significance: } * P<0.05 \text { vs. pair-fed rats; } \dagger P<0.05 \text { vs. } \\
\text { respective plasma albumin FSR; } \ddagger \text { calculated from stable tracer. }\end{array}$} \\
\hline
\end{tabular}

\section{Albumin Turnover}

Results on albumin synthesis measured in plasma and in liver are presented in Table 3. In plasma, albumin FSR increased two days after infection because synthesis was $80 \%$ higher in infected rats than in pair-fed animals despite a decrease of plasma levels. By contrast, intravascular albumin ASR was not significantly different in the two groups. When similar data were obtained using a stable tracer, the albumin FSR increased $>50 \%$ more in infected rats than in pair-fed animals $(91.3 \pm 4.8$ vs. $58.2 \pm 1.7 \%$ /day for INF and PF rats, respectively) and the albumin ASR did not differ between the two groups (146 \pm 7 vs. $140 \pm 5 \mathrm{mg} /$ day for INF and PF rats, respectively). In liver, albumin synthesis as a fraction of total liver protein synthesis decreased by 50\% in infected rats compared with pair-fed rats, but absolute albumin synthesis was similar in the two groups. By contrast, infection stimulated liver albumin FSR by $60 \%$ (measured directly from the stable tracer incorporation into albumin, Table 3). The FSR of liver albumin can also be calculated from radioactive labeling data by dividing ASR by the liver albumin pool. The values obtained were not significantly different from the values mea-

Table 4. Effect of infection on the synthesis of acute-phase proteins

\begin{tabular}{lcc}
\hline \hline & Pair-Fed Rats & Infected Rats \\
\hline FSR, \%/day & $82.2 \pm 8.5$ & $125.1 \pm 5.0^{*}$ \\
ASR, mg/day & $411 \pm 14$ & $573 \pm 41^{*}$ \\
\hline
\end{tabular}

Infected and pair-fed rats received a flooding dose of $\mathrm{L}-\left[{ }^{2} \mathrm{H}_{3}{ }^{14} \mathrm{C}\right]$ valine and were studied 2 days after infection. Calculations of FSR were made on total plasma protein minus albumin as an index of acute-phase protein synthesis. ASR was then calculated as the product of FSR times plasma total protein concentration $(\mathrm{g} / \mathrm{l})$ times plasma volume $(\mathrm{ml})$. Values are means $\pm \mathrm{SE}$ for $n=6$ for the 2 groups. Statistical significance: $* P<0.05$ vs. pair-fed rats. sured with the stable tracer $(404 \pm 82$ and $757 \pm$ $73 \% /$ day for $\mathrm{PF}$ and INF rats, respectively).

\section{Albumin Gene Expression}

Northern blot analysis showed that liver albumin mRNA levels (Fig. 2) were significantly reduced in septic animals compared with pair-fed rats. Total liver RNA content was increased by $54 \%$ in infected rats compared with pair-fed animals. However, infection resulted in a decrease of albumin mRNA per liver (Table 5).

\section{DISCUSSION}

Injection of live bacteria in rats reproduced principal changes observed in sepsis, i.e., a reduction in food intake, a fall in body weight, and an increased liver protein synthesis. In the present study, liver total protein synthesis, both as FSR and ASR, was increased with infection (by 2 and 3 times, respectively). Nevertheless, according to the severity of infection, this augmentation is more pronounced with our sepsis model than in others, for example the catabolic model including LPS (13) or zymosan administration (29). The response of liver to sepsis was also characterized by a $50 \%$ increase in RNA content, thus suggesting an increase in the capacity of protein synthesis. Liver synthesized both exported and nonexported proteins. Although the synthesis of constitutive proteins was

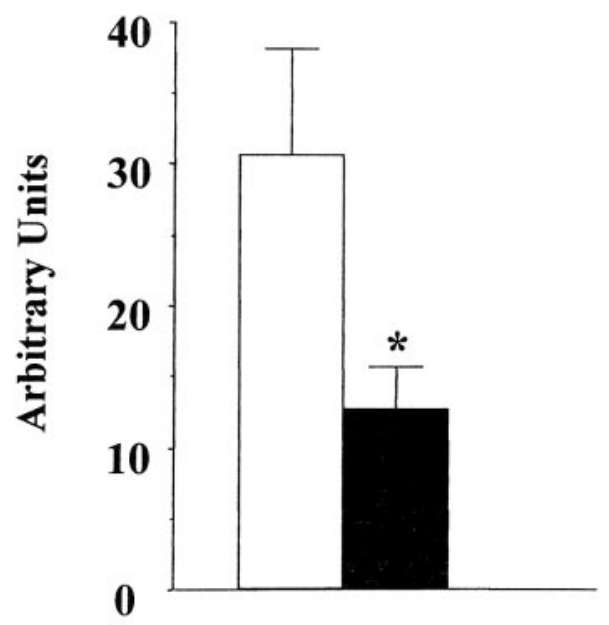

\section{$1.95 \mathrm{~Kb}$}

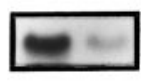

$18 \mathrm{~S}$

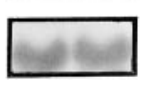

Fig. 2. Effect of infection on albumin mRNA levels. RNA was extracted from liver of pair-fed rats (open bar) and infected rats (dark bar) 2 days after infection. Samples $(20 \mu \mathrm{g})$ were electrophoresed, transferred to nylon membranes, and hybridized with $\left[{ }^{32} \mathrm{P}\right] \mathrm{cDNA}$ encoding albumin. After probes were stripped, blots were rehybridized with an 18S ribosomal oligonucleotide. Data were corrected for 18S rRNA abundance to take into account variations in RNA loading. Values are means $\pm \mathrm{SE}$ for 6 rats. ${ }^{*} P<0.05$ vs. pair-fed animals. Representative Northern blots and control band for the $18 \mathrm{~S}$ ribosomal RNA are also shown. 
Table 5. Effect of infection on albumin $\mathrm{mRNA}$ and total RNA levels in rat liver

\begin{tabular}{lcc}
\hline \hline & Pair-Fed Rats & Infected Rats \\
\hline Albumin mRNA, & & \\
$\quad$ arbitrary units & $30.8 \pm 7.4$ & $12.7 \pm 2.9^{*}$ \\
Total liver RNA, mg & $63.6 \pm 2.0$ & $98.0 \pm 1.8^{*}$ \\
Albumin mRNA per liver & $1.0 \pm 0.16$ & $0.64 \pm 0.15^{*}$ \\
\hline
\end{tabular}

Rats received an iv injection of either live E. coli (Infected) or saline (Pair-fed) and were studied 2 days after injections, during the acute septic period. Northern blots were prepared as described in METHODS. Albumin mRNA was corrected for 18S rRNA abundance. Albumin mRNA per liver was calculated by multiplication of albumin mRNA level with total liver RNA content. For convenience, values for relative albumin mRNA and albumin mRNA per liver of the pair-fed group were set at 1.0. Values are means \pm SE for $n=$ 10 for the 2 groups. Statistical significance: $* P<0.05$ vs. pair-fed rats.

stimulated in injury, there was a preferential stimulation of secreted proteins (39). Therefore, infection is accompanied by modifications of plasma concentrations of a large group of proteins originated from liver and known as APP. We found an increased plasma level of A1GPA, A2MG, and fibrinogen, confirming a profound inflammatory state in our model. To evaluate the mean synthesis rate of these proteins, the synthesis of total plasma proteins minus albumin was measured in the plasma. Both FSR and ASR were increased in infected compared with pair-fed animals. Nevertheless, the increased APP ASR in response to infection is probably underestimated, because the fraction of plasma proteins without albumin also contained proteins that were reduced in concentration, such as transferrin or retinol binding protein.

However, albumin is the major protein secreted by the liver, because it represents $\sim 50 \%$ of the productive effort at any moment (30) and its synthesis amounts to $11-18 \%$ of total liver protein synthesis in well-fed animals $(27,34)$. Moreover, it is the principal negative $\mathrm{APP}$, and a reduction in its plasma concentration is observed in various diseases. In the septic model used in this study, we found that albumin plasma levels fell by $34 \%$ in response to infection. Plasma albumin level is the net result of three active physiological processes occurring simultaneously. These include synthesis (entirely in the liver), distribution, and degradation. A dramatic fall in plasma concentration of albumin under stress could result from altered distribution between extra- and intravascular compartments, increased rate of degradation, or reduced rate of synthesis. The last hypothesis is the most widely accepted but not entirely demonstrated, and most studies compared treated animals with well-fed rats (2). In a situation in which animals ate less, such hypoalbuminemia may be as much a result of protein calorie undernutrition as of a negative acute-phase response.

Albumin level and synthesis are well known to be influenced by nutritional status (21). The influence of a protein-deficient diet on albumin kinetics in vivo was investigated by Pain et al. (25). In their study, albumin synthesis fell from normal values of $15 \%$ of the total liver protein synthesis to $\sim 8 \%$. Because infection induces an acute anorexia, the data obtained in this study were systematically compared with pair-fed control animals. In the control group receiving a limited amount of food, albumin synthesis, both as a proportion of total hepatic protein synthesis and as absolute synthesis, was in agreement with values previously reported in fasted rats that received no food for $18 \mathrm{~h}$ (27). Moreover, in the present investigation, hepatic FSR of albumin was calculated directly from the incorporation of stable isotope into the protein. Liver albumin FSR can also be estimated from relative albumin synthesis applied to total liver protein synthesis, i.e., albumin ASR and liver albumin content. In the current study both values were in agreement. There are no data for comparison in the literature about intrahepatic albumin FSR. The high value obtained may be explained by the small amount of residual hepatic albumin. In fact, we found $2.46 \mathrm{mg}$ of albumin per gram of liver in the pair-fed group; that represents $\sim 1.4 \%$ of total protein in the liver homogenate. This result is similar to the value of $1.6 \%$ reported by Schreiber et al. (35) in livers of normal rats.

Our results allow the comparison in the same experiment of albumin synthesis rate between two sites of measurement. We would have expected to find a greater synthesis of albumin in the liver than the value estimated in the intravascular compartment. Surprisingly, values of intrahepatic albumin ASR were not significantly different from those obtained from the plasma pool. The similar ASR of albumin in the two compartments support the idea that equilibration between hepatic and circulating albumin is rapid. Thus all newly synthesized albumin can appear in the plasma, and no significant amount has left it in the short time of the experiment. The daily loss of albumin to the extravascular spaces (identified by the transcapillary escape rate; TER) represents $\sim 5 \% / \mathrm{h}$ in healthy humans (26) and $24 \% / \mathrm{h}$ in rats (16). This value would indicate that, within $30 \mathrm{~min},<12 \%$ of plasma albumin exchanged with the interstitial compartment. This amount is perhaps too low to be detected significantly, given the uncertainties of the method used.

On the basis of numerous animal studies, it was usually admitted that a reduced synthesis is a predominant factor to explain the hypoalbuminemia observed in inflammation (1). Schreiber et al. (32) deduced a decrease in the synthesis of albumin from a decrease of liver mRNA levels in rats suffering from an acute inflammation induced by subcutaneous turpentine injection. Similar results were described in scalded rats (36) and after IL-1 $\beta$ injection (2). In the present work, the analysis of liver albumin mRNA levels also showed a decrease during the experimental acute-phase period in septic rats. This reduction in albumin mRNA levels agreed well with the decreased relative albumin synthesis expressed as a fraction of total liver protein synthesis. It should be mentioned that mRNA levels represent the albumin mRNA content as a percentage of total mRNA. Therefore, decreased albumin mRNA levels can be obtained without any change in albumin 
mRNA content if total mRNA increased. These findings are in line with those proposed by Ballmer et al. (2) despite a greater effect from use of ad libitum-fed control animals. By contrast, absolute albumin synthesis was not altered by the infection, whereas mRNA content of the protein was reduced. Nevertheless, it would be more exact to express steady-state level of albumin mRNA in comparison with total mRNA instead of total RNA. In this aspect, Lewandowski et al. (17) reported a correlation between the relative amount of albumin mRNA translational activity of poly(A)-containing RNA and albumin synthesis in the liver. The net result observed in this work is similar variations in both albumin mRNA and synthesis, which provided evidence that transcriptional mechanisms play a central role in the regulation of expression of albumin. Finally, a fall in albumin mRNA levels is a good representation of relative albumin synthesis (as a portion of total hepatic protein synthesis) but could not be interpreted as a decrease in net intrahepatic albumin synthesis.

Few studies have been performed in vivo on albumin synthesis in either plasma or liver after injury in animals. The present study shows that the FSR of albumin, measured in the plasma pool, increased in response to infection, and that both plasma and liver albumin ASR was not altered after infection. These results are not in agreement with those obtained by Schreiber et al. (33), who reported that incorporation of radioactive leucine into plasma albumin is reduced in turpentine-treated rats, suggesting that albumin synthesis is decreased during inflammation. Similar results were obtained under infection in rats (28) or during heat exposure in rabbits (24). Ballmer et al. (2) investigated albumin synthesis both as a fraction of total liver protein synthesis and as ASR $24 \mathrm{~h}$ after turpentine injection; albumin synthesis relative to total liver protein synthesis was decreased by $68 \%$, and albumin ASR was decreased by $42 \%$. However, in all these studies, the decrease in albumin synthesis in treated anorexic animals was observed by comparison with well-fed animals. Therefore, the decreased synthesis observed may result from the decreased food intake rather than from the inflammatory stress. By contrast and in agreement with our observation, Hiyama et al. (12) reported an unchanged albumin absolute synthesis in isolated liver of burn rats. Moreover, injection of endotoxin in rabbits stimulated by $15 \%$ the ASR of albumin in the plasma (15).

By contrast to animal studies, results of human albumin kinetics under several injuries have become more available in the last few years. Kaysen et al. (14) reported a $20 \%$ decrease in albumin synthesis in hypoalbuminemic hemodialysis patients compared with hemodialysis patients with normal albumin levels. Moshage et al. (22) suggested that infected patients who have very low plasma levels presented higher values in albumin FSR. Both albumin FSR and ASR were increased in head trauma patients with a severely depressed plasma albumin level (19). Therefore, it is increasingly accepted that low levels of plasma albumin can be obtained without decrease of albumin synthesis. Stress hormones could be implicated in maintaining albumin synthesis in injury. In particular, De Feo et al. (8) showed in humans that glucocorticoids stimulate synthesis of albumin. These hormones may exert their effects directly on the liver cells by affecting a number of subcellular processes involved in protein synthesis.

In conclusion, this work investigates simultaneously liver and intravascular albumin synthesis in vivo in a septic rat model. Our data clearly confirm a fall of albumin mRNA levels in response to infection parallel to a decrease in intrahepatic albumin synthesis expressed as a fraction of total liver protein synthesis; they give evidence that mRNA levels cannot be interpreted in terms of absolute protein synthesis. Moreover, the depressed plasma levels of albumin were not associated with a reduced hepatic albumin synthesis. This study also demonstrated that plasma albumin synthesis rate is a good indicator of net liver synthesis rate during an early phase of sepsis. Such results could have potential clinical implications, because the intravascular compartment, easily accessible, represents $<35 \%$ of the total exchangeable albumin pool. Because we observed no decrease of plasma albumin synthesis rate during the acute phase, hypoalbuminemia could be due to an increase in either catabolism or escape of the protein from the plasma pool in the extravascular space. In this respect, the albumin TER was found to be increased by $300 \%$ in infected patients (10). Further experiments are required to determine the major factor causing hypoalbuminemia in injury.

We thank Drs. Y. Akira and K. Nakamura (Department of Applied Biological Sciences, Nagoya University, Nagoya, Japan) for providing albumin cDNA. We also thank Caroline Buffière and Philippe Denis for technical assistance and H. Lafarge for literature acquisition.

This work was supported by Nestlé, the French Ministère de l'Education Nationale de la Recherche et de la Technologie, and the Institut National de la Recherche Agronomique.

\section{REFERENCES}

1. Aldred AR and Schreiber G. The negative acute phase proteins. In: Acute Phase Proteins. Molecular Biology, Biochemistry, and Clinical Applications, edited by A Mackiewicz, I Kushner, and H Baumann. London: CRC, 1993, p. 21-38.

2. Ballmer PE, McNurlan MA, Grant I, and Garlick PJ. Downregulation of albumin synthesis in the rat by human recombinant interleukin-1 $\beta$ or turpentine and the response to nutrients. J Parent Enteral Nutr 19: 266-271, 1995.

3. Ballmer PE, McNurlan MA, Milne E, Heys SD, Buchan V, Calder AG, and Garlick PJ. Measurement of albumin synthesis in humans: a new approach employing stable isotopes. Am $J$ Physiol Endocrinol Metab 259: E797-E803, 1990.

4. Beisel WR. Metabolic effects of infection. Prog Food Nutr Sci 8: 43-75, 1984.

5. Breuillé D, Rosé F, Arnal M, Melin C, and Obled C. Sepsis modifies the contribution of different organs to whole-body protein synthesis. Clin Sci (Colch) 86: 663-669, 1994.

6. Breuillé D, Voisin L, Contrepois M, Arnal M, Rose F, and Obled C. A sustained rat model for studying the long-lasting catabolic state of sepsis. Infect Immun 67: 1079-1085, 1999.

7. Chomczynski $\mathbf{P}$ and Sacchi S. Single-step method of RNA isolation by acid guanidinium thiocyanate-phenol-chloroform extraction. Anal Biochem 162: 156-159, 1987. 
8. De Feo P, Horber FF, and Haymond MW. Meal stimulation of albumin synthesis: a significant contributor to whole body protein synthesis in humans. Am J Physiol Endocrinol Metab 263: E794-E799, 1992.

9. Fearon KC, Falconer JS, Slater C, McMillan DC, Ross JA, and Preston T. Albumin synthesis rates are not decreased in hypoalbuminemic cachectic cancer patients with an ongoing acute-phase protein response. Ann Surg 227: 249-254, 1998.

10. Fleck A, Raines G, Hawker F, Trotter J, Wallace PI, Ledingham I, and Calman KC. Increased vascular permeability: a major cause of hypoalbuminemia in disease and injury. Lancet 1 : 781-784, 1985.

11. Garlick PJ, McNurlan MA, and Preedy VR. A rapid and convenient technique for measuring the rate of protein synthesis in tissues by injection of $\left[{ }^{3} \mathrm{H}\right]$ phenylalanine. Biochem $J$ 192: 719-723, 1980.

12. Hiyama DT, Von Allmen D, Rosenblum L, Ogle CK, Hasselgren PO, and Fischer JE. Synthesis of albumin and acutephase proteins in perfused liver after burn injury in rats. J Burn Care Rehabil 12: 1-6, 1991.

13. Jepson MM, Pell JM, Bates PC, and Millward DJ. The effect of endotoxaemia on protein metabolism in skeletal muscle and liver of fed and fasted rats. Biochem J 235: 329-336, 1986.

14. Kaysen GA, Yeun J, and Depner T. Albumin synthesis, catabolism and distribution in dialysis patients. Miner Electrolyte Metab 23: 218-224, 1997.

15. Koj A and McFarlane AS. Effect of endotoxin on plasma albumin and fibrinogen synthesis rates in rabbits as measured by the ${ }^{14} \mathrm{C}$ carbonate method. Biochem $J$ 108: 137-146, 1968.

16. Krähenbühl S, Marti U, Grant I, Garlick PJ, and Ballmer PE. Characterization of mechanisms causing hypoalbuminemia in rats with long-term bile duct ligation. J Hepatol 23: 79-86, 1995.

17. Lewandowski AE, Liao WSL, Stinson-Fisher CA, Kent JD, and Jefferson LS. Effects of experimentally induced nephrosis on protein synthesis in rat liver. Am J Physiol Cell Physiol 254: C634-C642, 1988.

18. Mancini G, Carbonara AO, and Heremans JF. Immunochemical quantitation of antigens by single radial immunodiffusion. Immunochemistry 2: 235-254, 1965.

19. Mansoor O, Cayol M, Gachon P, Boirie Y, Schoeffler P, Obled C, and Beaufrère B. Albumin and fibrinogen syntheses increase while muscle protein synthesis decreases in head-injured patients. Am J Physiol Endocrinol Metab 273: E898-E902, 1997.

20. Marinkovic S, Jarheis GP, Wong GG, and Baumann H. Il-6 modulates the synthesis of a specific set of acute phase plasma proteins in vivo. J Immunol 142: 808-812, 1989.

21. Morgan EH and Peters T. The biosynthesis of rat serum albumin. V. Effect of protein depletion and refeeding on albumin and transferrin synthesis. J Biol Chem 246: 3500-3507, 1971.

22. Moshage HJ, Janssen JAM, Franssen JH, Hafkenscheid JCM, and Yap SH. Study of the molecular mechanism of decreased liver synthesis of albumin in inflammation. J Clin Invest 79: 1635-1641, 1987.

23. Munro HN and Fleck A. Analysis of tissues and body fluids For nitrogenous constituents. In: Mammalian Protein Metabolism, edited by HN Munro. New York: Academic, 1969, p. 423-525.

24. Oratz M, Walker C, Schreiber S, Gross S, and Rothschild MA. Albumin and fibrinogen metabolism in heat- and coldstressed rabbits. Am J Physiol 213: 1341-1349, 1967.

25. Pain VM, Clemens MJ, and Garlick PJ. The effect of dietary deficiency on albumin synthesis and on the concentration of active albumin messenger ribonucleic acid in rat liver. Biochem $J$ 172: 129-135, 1978.

26. Parving $\mathbf{H}$ and Rasmussen SM. Transcapillary escape rate of albumin and plasma volume in short- and long-term juvenile diabetics. Scand J Clin Lab Invest 32: 81-87, 1973.

27. Peters T and Peters JC. The biosynthesis of rat serum albumin. VI. Intracellular transport of albumin and rates of albumin and liver protein synthesis in vivo under various physiological conditions. J Biol Chem 247: 3858-3863, 1972.

28. Powanda MC, Wannemacher RW Jr, and Cockerell GL. Nitrogen metabolism and protein synthesis during pneumococcal sepsis in rats. Infect Immun 6: 266-271, 1972.

29. Rooyackers OE, Sari WHM, Soeters PB, and Wagenmakers AJM. Prolonged changes in protein and amino acids metabolism after zymosan treatments in rats. Clin Sci (Colch) 87: 619-626, 1994

30. Rothschild MA, Oratz M, and Schreiber SS. Serum albumin. Hepatology 8: 385-401, 1988.

31. Sax HC, Talamini MA, Hasselgren PO, Rosenblum L, Ogle CK, and Fisher JE. Increased synthesis of secreted hepatic proteins during abdominal sepsis. J Surg Res 44: 109-116, 1988.

32. Schreiber G, Aldred AR, Thomas T, Birch HE, Dickson PW, Guo-Fen T, Heinrich PC, Northemann W, Howlett GJ, de Jong FA, and Mitchell A. Levels of messenger ribonucleic acids for plasma proteins in rat liver during acute experimental inflammation. Inflammation 10: 59-66, 1986.

33. Schreiber G, Howlett G, Nagashima M, Millership A, Martin H, Urban J, and Kotler L. The acute phase response of plasma protein synthesis during experimental inflammation. J Biol Chem 257: 10271-10277, 1982.

34. Schreiber G and Urban J. The synthesis and secretion of albumin. Rev Physiol Biochem Pharmacol 82: 27-95, 1978.

35. Schreiber G, Urban J, Zöhringer J, Reutter W, and Frosch $\mathbf{U}$. The secretion of serum protein and the synthesis of albumin and total protein in regenerating in rat liver. $J$ Biol Chem 14: 4531-4538, 1971.

36. Sevaljević L, Ivanović-Matić S, Petrović M, Glibetić M, Pantelić D, and Poznanović G. Regulation of plasma acutephase protein and albumin levels in the liver of scalded rats. Biochem J 258: 663-668, 1989.

37. Sharma RJ, Macallan DC, Sedgwick P, Remick DG, and Griffin GE. Kinetics of endotoxin-induced acute-phase protein gene expression and its modulation by TNF- $\alpha$ monoclonal antibody. Am J Physiol Regulatory Integrative Comp Physiol 262: R786-R793, 1992.

38. Smith PK, Krohn RI, Hermanson GT, Mallia AK, Gartner FH, Provenzano MD, Fujimoto EK, Goeke NM, Olson BJ, and Klenk DC. Measurement of protein using bicinchoninic acid. Anal Biochem 150: 76-85, 1985.

39. Vary TC and Kimball SR. Regulation of hepatic protein synthesis in chronic inflammation and sepsis. Am J Physiol Cell Physiol 262: C445-C452, 1992.

40. Voisin L, Breuillé D, Ruot B, Rallière C, Rambourdin F, Dalle M, and Obled C. Cytokine modulation by PX differently affects specific acute phase proteins during sepsis in rats. Am $J$ Physiol Regulatory Integrative Comp Physiol 275: R1412-R1419, 1998.

41. Von Allmen D, Hasselgren PO, and Fischer JE. Hepatic protein synthesis in a modified septic rat model. J Surg Res 48: 476-480, 1990. 